\title{
Climatic Zonality of Periglacial Landforms in Mountain Areas
}

\author{
STUART A. HARRIS
}

(Received 30 August 1993; accepted in revised form 24 January 1994)

\begin{abstract}
The alpine periglacial areas of the world can be divided into three distinctive landscape types dominated by one of the following: active rock glaciers, active block streams, or gelifluction landforms. These also correspond to distinct climates, the active rock glaciers occurring under cold, humid conditions; the active block streams in cold, dry climates; and gelifluction-dominated landforms occurring in warmer areas. These have distinct ranges of mean annual temperature and precipitation, which can be used in interpreting climatic changes based on distribution of fossil landforms.
\end{abstract}

Key words: alpine permafrost, block streams, rock glaciers, gelifluction

RÉSUMÉ. On peut diviser les régions périglaciaires alpines du globe en trois types de paysages distincts, dominés par un des éléments suivants : glaciers rocheux actifs, coulées de pierres actives ou reliefs de gélifluxion. Ces éléments correspondent aussi à des climats distincts, les glaciers rocheux existant dans des conditions de froid et d'humidité; les coulées de pierres actives sous des climats froids et secs; et les reliefs de gélifluxion dans des régions plus tempérées. Ces paysages ont des gammes différentes de moyennes annuelles de températures et de précipitations, qui peuvent servir à interpréter les changements climatiques fondés sur la distribution des reliefs fossiles.

Mots clés : pergélisol alpin, coulées de pierre, glaciers rocheux, gélifluxion

Traduit pour Arctic par Nésida Loyer.

\section{INTRODUCTION}

The major objective of the expeditions of the late Carl Troll was to explore the high mountain areas of the world so as to determine the variations in geomorphology and plant cover in these regions. The result was a remarkable collection of descriptions (e.g., Troll, 1972), but these were never integrated into a worldwide system.

The writer first visited the Alps in 1947 and has subsequently been fortunate to visit many more mountain ranges in different parts of the world. After 45 years of field work, it has become apparent that there may be a general worldwide zonation of dominant landforms in mountainous permafrost regions, and it is the purpose of this paper to describe some of the evidence for this.

During field work in cold mountain areas in various parts of the world, certain patterns of landforms have become apparent. This conclusion has been strengthened by recent publications by specialists on different mountain ranges. The main problem with the literature has been the dominance of works on certain accessible mountain ranges, e.g., the Alps, and English-speaking workers' inaccessibility to many other critical areas of the world, namely, Russia, Siberia, Central Asia, the People's Republic of China, and the Cordillera of South America. With increased access to these regions for Europeans and North Americans, and with the increasing availability of literature on these areas in languages other than Russian, Chinese, etc., it is now timely to attempt a zonation of the dominant alpine permafrost landforms. In this paper, examples are given of some of the key permafrost landforms from these newly accessible regions as well as from those that are better known.

\section{DEFINITIONS}

Three main groups of landforms dominate the zonation. Unfortunately, the names of two of the three groups have been under debate for a long time, so it is necessary to start with the definitions of the terms as used in this paper.

The term "active block stream" is used to refer to lines of angular or subangular blocks (Fig. 1) descending downslope as a stream (Washburn, 1973, 1979). The blocks have the same lithology as the underlying material, whether that be bedrock or a superficial deposit containing blocks. The blocks are apparently moved upwards and ejected from the soil or broken from the bedrock by frost action (King and Hirst, 1964; Joyce, 1950). There is little sign of rounding or chemical weathering, and they usually exhibit a sharp boundary with the surrounding deposits. They move at a rate of several centimetres per year (Romanovskii and Tyurin, 1983) and the movement may be due to creep of thawed blocks over an icy base (Czudek and Demek, 1972; Romanovskii and Tyurin, 1983) when the ice content in winter exceeds $50 \%$ by volume. Ice contents of up to $90 \%$ by volume in winter have been reported by Romanovskii and Tyurin (1983:1097) from southern Yakutia and northern Transbaikalia.

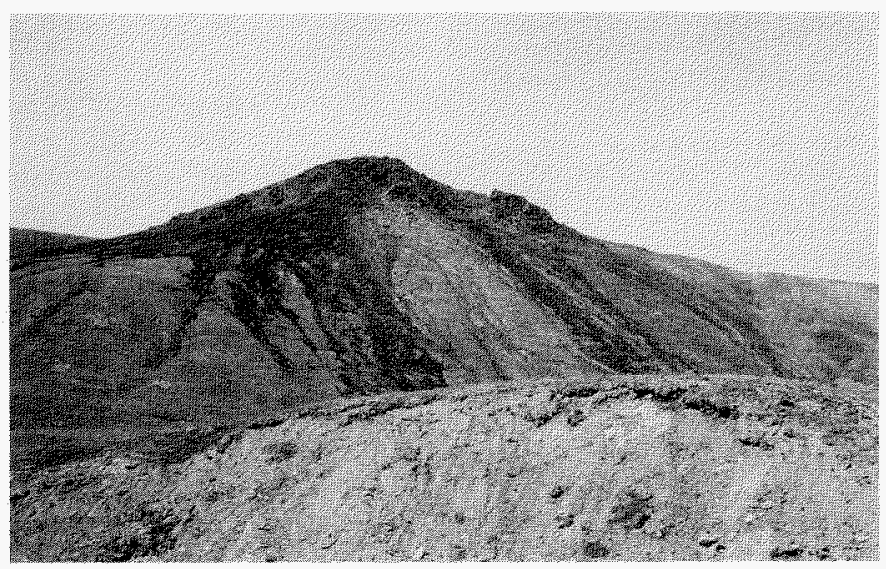

FIG. 1. Active rock streams, Kunlun Shan, China. 
These landforms must be clearly differentiated from "stone runs" (Geike, 1894; Andersson, 1906), which are streams of subrounded or rounded boulders lying on slopes. In these cases, water has removed the finer material from between the boulders and has aided in chemical and physical weathering of the blocks, increasing their roundness. These can be observed forming today - for example, at the Upper Glaciological Station, Tien Shan, near Urumqi - from sorted patterned ground and till. They differ from the deposits of blocky "debris flows" in the bottoms of gullies by the absence of finer material in the deposit, the absence of lateral levees, the lack of a hollow up-valley where the blocks came from, and the slow movement that mainly occurs in winter. They probably grade into certain kinds of "block slopes", which are slopes greater than $10^{\circ}$ (Washburn, 1979) mantled in blocks of rock. Some of these slopes at maximum angle of rest of material are called "talus slopes" and also show slow downslope movements (e.g., Luckman, 1988), but the nature of the movement is quite different (Loughran and Loughran, 1979; Gardner, 1979; Kotarba, 1984; Kotarba and Strömquist, 1984; Luckman, 1988; Pérez, 1989, 1993). However, ongoing studies by the author and his students on edaphically dry block slopes at Plateau Mountain, southwestern Alberta, show similar processes occurring to those on active block streams. Active block streams differ from the other landforms in always occurring in cold climates in the active layer overlying permafrost.

The term "active rock glacier" is used in this paper to refer to masses of rock debris containing substantial quantities of interstitial ice and moving slowly downslope as a sheet. The rocks are matrix supported in the ice, which may reach $60 \%$ by volvme (Barsch, 1978). The movement is normally most rapid in the centre, decreasing towards the sides and terminus (Jackson and MacDonald, 1980; Gorbunov et al., 1992). This differential movement causes an oversteepening of the front slope (Fig. 2). Movement is now believed to be due to deformation and flow of the ice in the interior of the mass (Haeberli, 1985), sometimes aided by zones of high hydrostatic pressure (Giardino, 1983). Good examples of factors affecting the movement of rock glaciers will be found in Gorbunov et al. (1992).

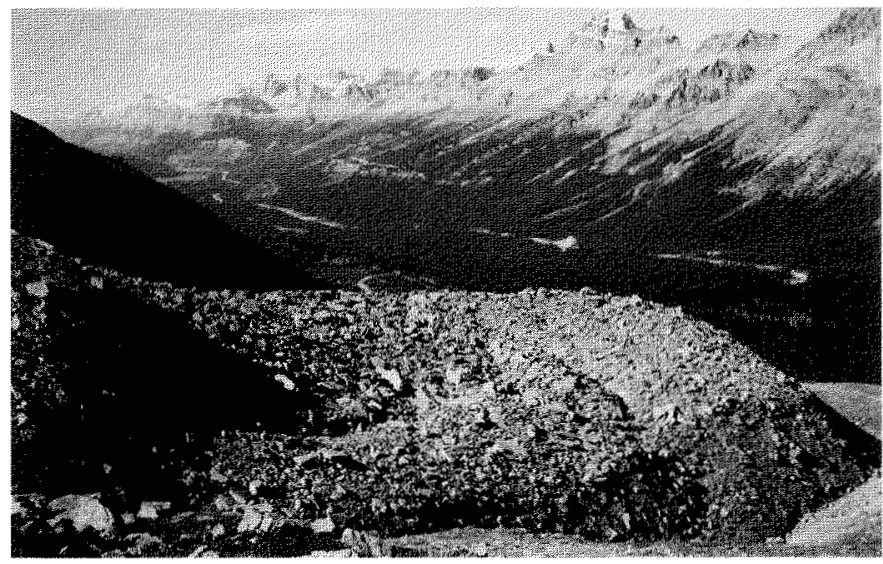

FIG. 2. Rock glacier above Bow Summit, Banff National Park. Alberta, Canada.
The third major group of landform comprises the "gelifluction" deposits. The original term used for flowage of saturated soil downslope over a relatively impermeable substrate was "solifluction" (Andersson, 1906). However, this could include flowage over an unfrozen clay layer, which can occur in any climate, although it is relatively uncommon. Gelifluction was defined by Baulig (1956:50-51) as flowage of wet, unfrozen soil downslope over a frozen substrate. The latter may be either seasonal or perennial frost (permafrost). It is therefore movement of the upper layer of the superficial deposits that takes place, and the most extensive examples appear to be the deposits described as the "Kunlun Shantype rock glacier" (Fig. 3) of Cui (1983). The front of these features has a low slope (Fig. 4) and the deposits exhibit small lobes on the surface due to soil flowage when snow melts (Fig. 5). Larger blocks act as braking blocks (Fig. 6), since the active layer in the main mass at this site is rarely over $50 \mathrm{~cm}$ thick. Thus blocks of rock more than $1 \mathrm{~m}$ in diameter are permanently frozen into the ground, and the moving superficial material piles up behind them. The movement is also indicated by elongation upslope of the roots and/or stems of the few plants growing on the landform (Fig. 7) in these areas of relatively rapid movement, where most plant species cannot survive. Braking blocks are a good indicator of gelifluction on a slope in cold climates.

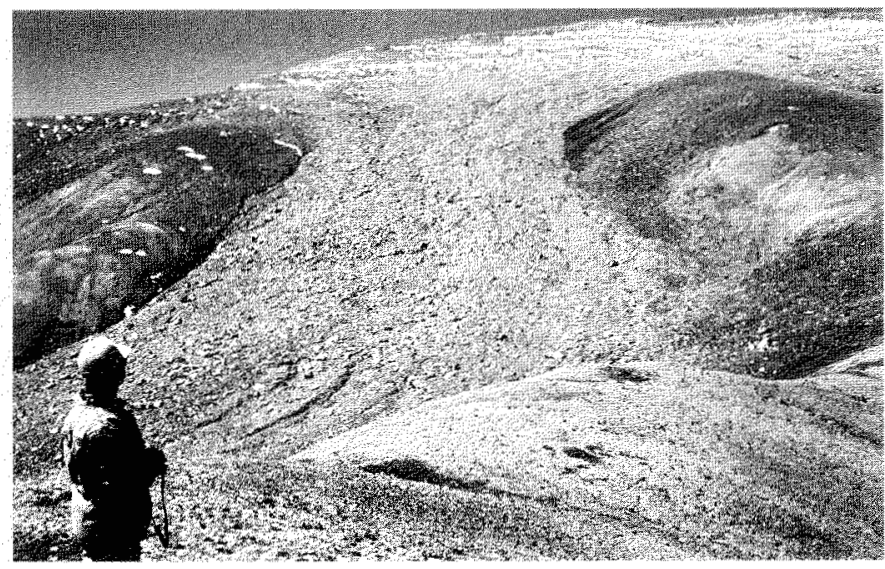

FIG. 3. Active gelifluction deposit moving down a valley floor, Kunlun Shan Note the contrast between the vegetated ridges and the bare active material.

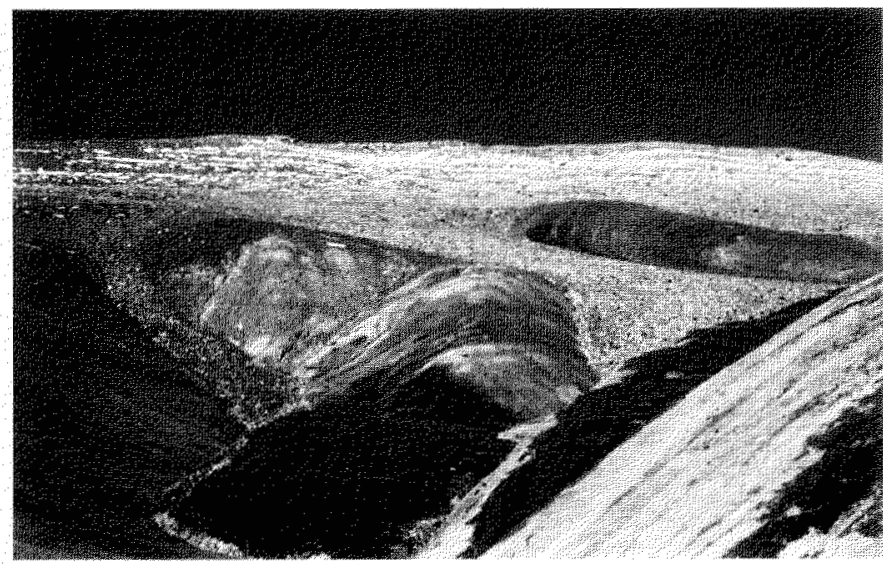

FG. 4. Front of an active gelifluction deposit (the Kunlun Shan-type rock glacier) on the north slope of the Kunlun Shan. 


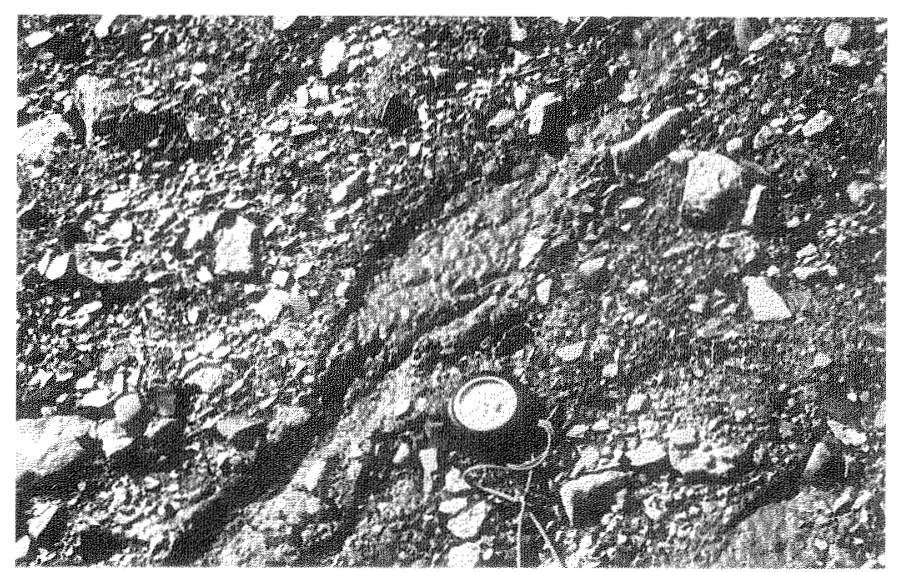

FIG S. Gelftuction on the surface of Kunlun shan rock vacier number 6 .

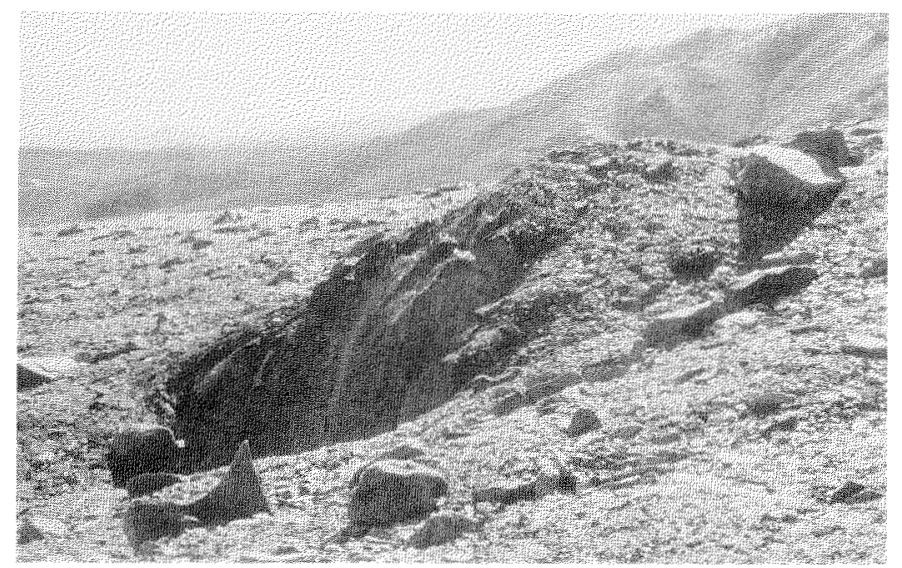

FG, 6 . Braking block being overridden by finer material on Kunun shan rock glacier number 6

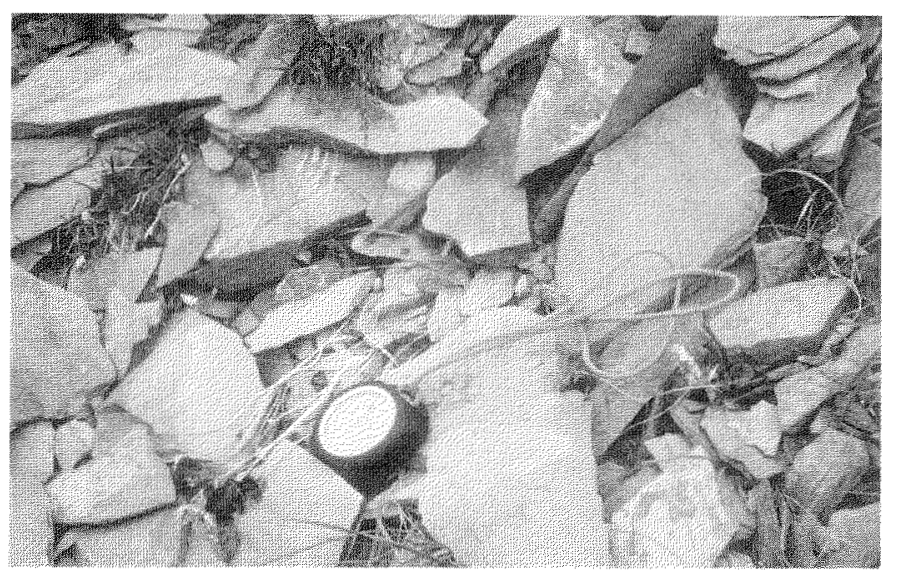

Fo. 7. Elongation of the stems of Aster himalaks on an active block strean, $4800 \mathrm{~m}$ elevation. Kunlun Shan.

Other landforms produced by gelifluction include gelifluction lobes, sheets, benches, and streams (Washburn, 1979:206). The gelifluction features of the Kunlun Shan are examples of gelifluction sheets and streams. Turf-banked terraces and stone-banked terraces and lobes (Benedict, 1970, 1976; Smith, 1987, 1988) are examples of the lobes and benches of Washburn. In extreme cases, gelifluction can smooth out large surfaces, producing altiplanation terraces
(Eakin, 1916:77-82), equiplanation terraces (Cairnes, 1912:344-348), and goletz terraces (Jorré, 1933), all of which are now usually called cryoplanation terraces (Bryan, 1946:639-640). These gently sloping surfaces cut across the bedrock structure and it is argued that they are developed by gelifluction, since gelifluction deposits form a veneer over bedrock (Fig. 8), often with patterned ground or ice wedges developed on them (Fig. 9). Gelifluction lobes may occur on their surfaces, as on the west side of the Mackenzie Mountains, Yukon Territory (Fig. 10). French and Harry (1992) argue that it remains to be proven that cryoplanation terraces in unglaciated terrain are formed under the present climate (e.g., those in Fig. 8), but some cases can be found where they are present on Late Wisconsinan till (Fig. 11) in central Alaska. These must have been formed during the Holocene.

Where the frost is deep but seasonal, gelifluction produces ploughing blocks, and these can also occur where there is a deep active layer over permafrost, for example, at Marmot Basin, Jasper, Alberta. The moisture is supplied by melting snow and the heavy rocks tend to move downslope faster than the surrounding sediments (see Gorbunov, 1991).

Gelifluction occurs on most slopes with medium- to finegrained material present in areas of freezing ground. It can

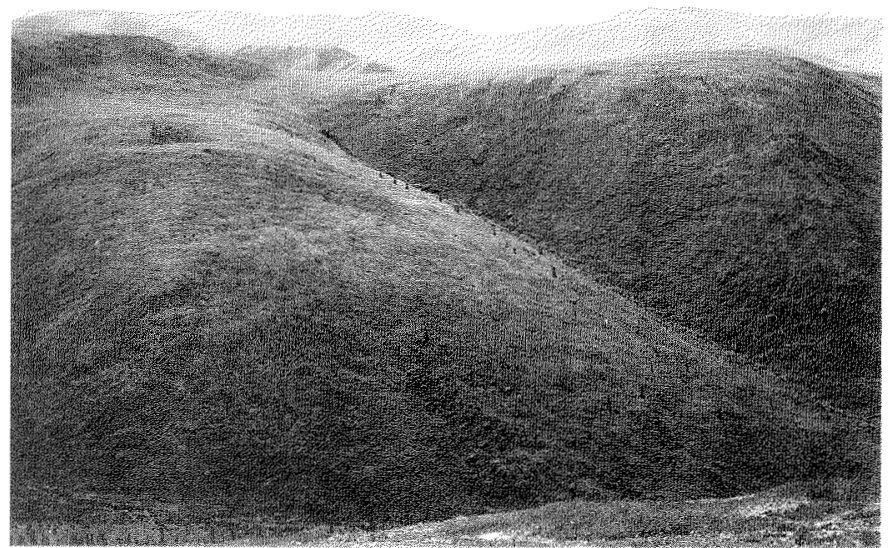

Fo. C. Cryoplanation surface cuting across the rock structure east of Bondary, Top ot the World Highway, Yukon, Canada.

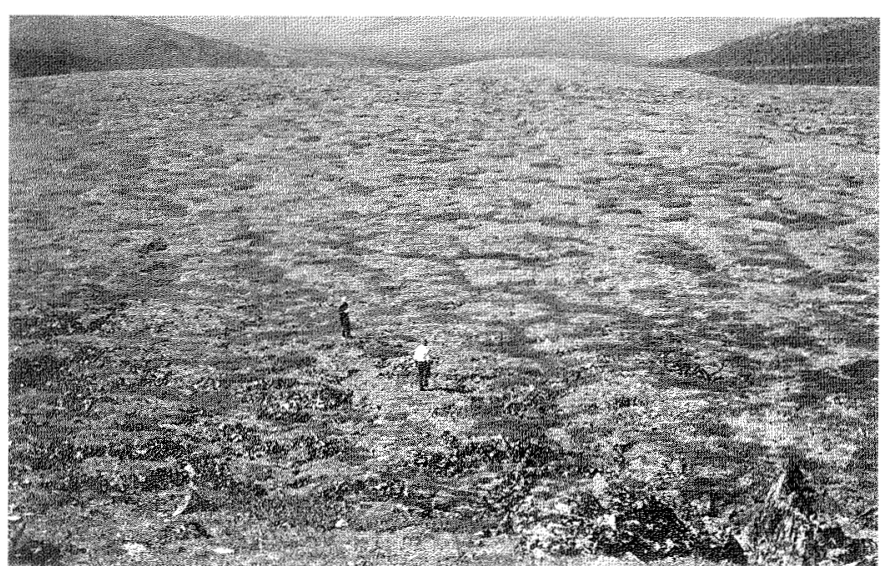

Fo. 9. Pattemed ground on the cryoplanation surface, east of Boundary Top of the World Tighway. Yukon. 


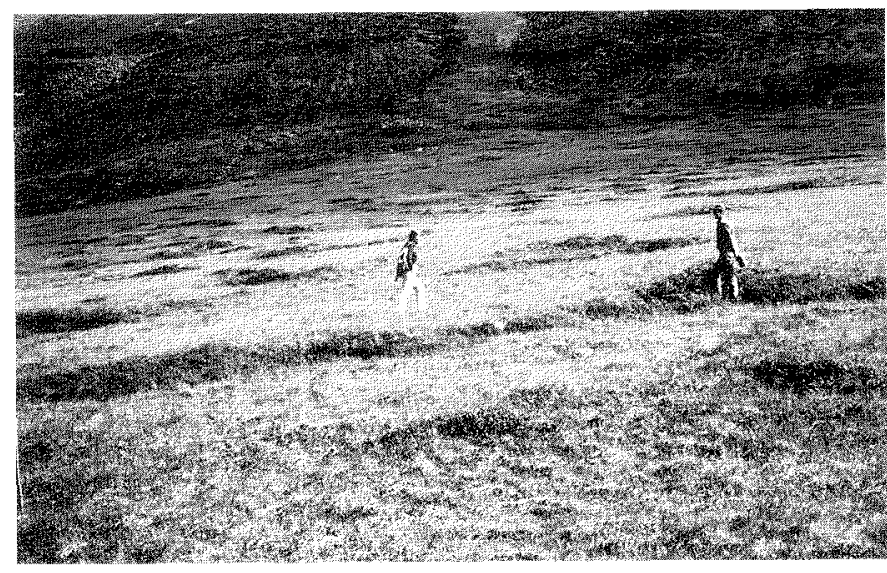

Fic. 10. Gelintuction lobes, developed on a cryoplanation surface on west side of the Rat Pass, Dempster Highway, Yukon Territory.

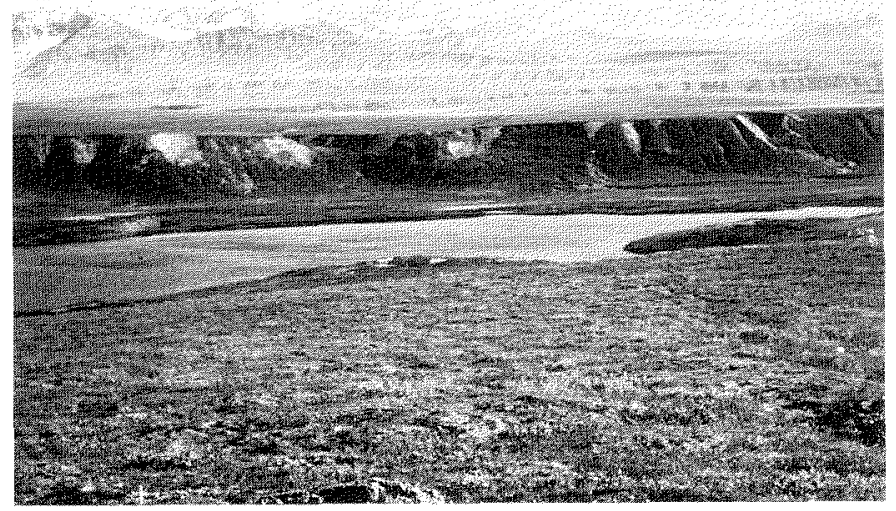

FIo. 11. View of the Alaska Range from the south, Denali Highway Alaska, showing cryoplanation teraces developed on late Wisconsin till

occur on rock glaciers if there is fine-grained material present in the matrix on the surface of the landform, such as in the rock glaciers in the PreCordillera of Argentina near Mendoza (Fig. 2), and in these cases results in the presence of braking blocks as the finer unfrozen material flows downslope, overriding the large blocks still frozen in the underlying permafrost.

Gelifluction is a slow surface phenomenon, in contrast to rapid, catastrophic flows such as debris flows and detachment failures or active layer detachment flows and skin flows (see Hughes, 1972; McRoberts and Morgenstern, 1974; Harris et al., 1988). All these other processes result in a hollow where the material came from and a cone-shaped undulating accumulation area. These are local phenomena and rarely dominate the landscape, but are often found in association with gelifluction. Similarly, the retrogressive thaw-flow slides and retrogressive thaw slumps consist of various combinations of catastrophic slides and debris flows, together with gelifluction, but the slides and debris flows dominate the resulting landforms (Mackay, 1966; Rampton and Mackay, 1971; Hughes, 1972; McRoberts and Morgenstern, 1974; Washburn, 1979; Harris and Gustafson, $1988,1993)$. Since these are caused primarily by highly icerich permafrost, they are more important as local phenomena than as major worldwide processes.
The degree of activity of both block streams and rock glaciers may be gauged by the absence of lichens and vascular vegetation (Figs. 3, 5, 6). Measurements of the rates of movement on the surface of the main bodies of either landform are essential to prove this activity, however, since the lower parts of some active rock glaciers may be covered in forest (Blumstengel and Harris, 1988). The margins of active rock glaciers may show negligible movement (Jackson and MacDonald, 1980), and the front of the rock glacier may continue to reduce its oversteepened slope long after movement in the main mass has ceased.

\section{ZONATION OF THE DOMINANT ALPINE PERMAFROST LANDFORMS}

\section{Geographical Distribution}

Figure 12 shows the distribution of the mountain areas dominated by each of these three basic groups of landforms. Active block streams are best developed in Siberia (Romanovskii and Tyurin, 1974, 1983) and in the Urals (Romanóvskii and Tyurin, 1986). They have also been seen by the writer in the Kunlun Shan in China and in the Richardson Range in northwest Canada.

Rock glaciers are widespread in the Alps (Capello, 1947; Evin, 1983; Haeberli, 1991), in the Cordillera of western Canada and Alaska (Capps, 1910; Wahrhaftig and Cox, 1959; Luckman and Crockett, 1978; Kershaw, 1978; Ellis and Calkin, 1980), in Argentina (Catalano, 1926; Marangunic, 1976; Corte, 1976, 1985; Igarzabal, 1983), and in isolated localities through Eastern Europe and the Middle East (Grötzbach, 1965; Schweizer, 1972; Gobadzhishvili, 1978). They also occur in the high mountains of the Tien Shan (Palgov, 1948; Gorbunov, 1983; Titkov, 1985; Gorbunov et al., 1992) and on the north slope of the Hindu Kush in Afghanistan and India (Rathjens, 1978; Mayewski et al., 1981).

Gelifluction landforms dominate elsewhere. They are found in the Cordillera of North America wherever permafrost is present, from Kananaskis, Alberta, southwards to about $20^{\circ} \mathrm{S}$ in the Andes of South America (Troll, 1947; Schubert, 1969;

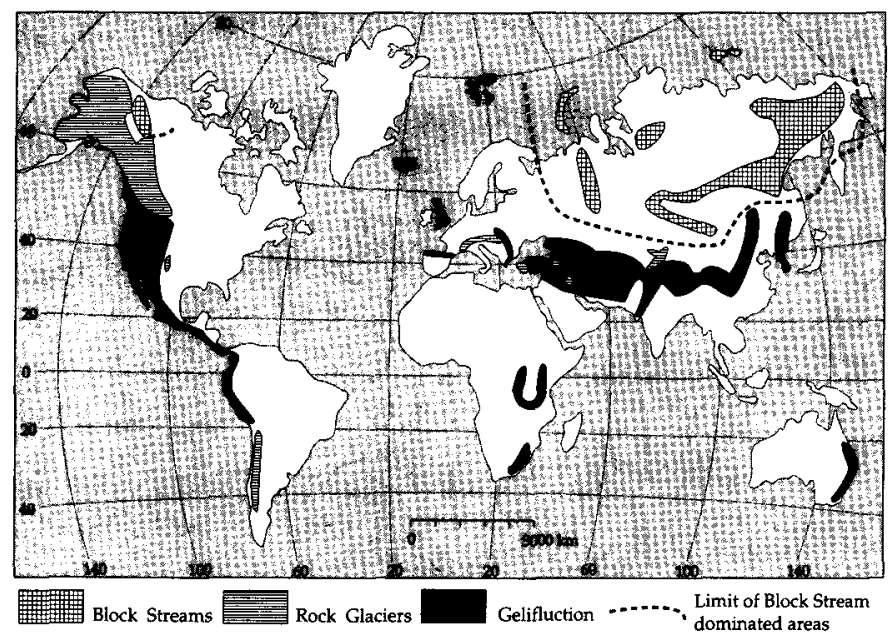

FIG. 12. Worldwide distribution of mountain areas dominated by active block streams, active rock glaciers, and active gelifluction deposits. 
Graf, 1984; Pérez, 1985, 1988; Francou, 1988; Smith, 1988). The gelifluction zone is also found in East Africa (Sparrow, 1967; Hastenrath and Wilkinson, 1973) and through most of the belt between the Pyrenees and southeast Siberia, including Iran, Tibet, central China, Korea, and Japan (e.g., Zhigarev, 1967).

\section{DISCUSSION}

\section{Relationship of These Features to Climate}

Figure 13 shows the results of plotting the data for mean annual air temperature and mean annual precipitation for typical weather stations in the landscapes dominated by each of the three landscape types. Each occupies a discrete zone on the graph and there is remarkably little overlap. Note that the zones of distribution are merely picked out by drawing lines around the data points for all the weather stations where a particular landform dominates the landscape. No statistical manipulation has been performed. Part of the source data is listed in Table 1.

The overlap that does occur is probably due to a combination of five factors. First, the measurements of precipitation are not particularly accurate. There is little problem in measuring rainfall, but over half the precipitation is in the form of snowfalls. Snowfall is notoriously difficult to measure (Harris, 1972, 1973) and there is the additional problem that it can be redistributed by wind. Second, there is a considerable difference in the effect of a given amount of precipitation on coarse-grained soils, such as sands, and fine-grained soils, such as silts and clays. Third, many of the weather stations are located on valley floor sites as opposed to the mountain peaks. Fourth, the decision as to which of the three landforms is dominant in the landscape is not truly quantitative. Last, to form block streams or rock glaciers, suitable rock materials must be present. With more data, the degree of overlap should become apparent, and an overlap may occur between gelifluction and block stream-dominated landscapes.

Nonetheless, some broad relationships can be recognized. The landscapes of the warmer periglacial climates are dominated by gelifluction and debris flows. Rock glaciers are the characteristic landforms of landscapes in colder, wetter climates, whereas active block streams are the outstanding landscape features in cold, dry climates. At the same time there are zones of overlap around the field dominated by rock glaciers in Figure 13.

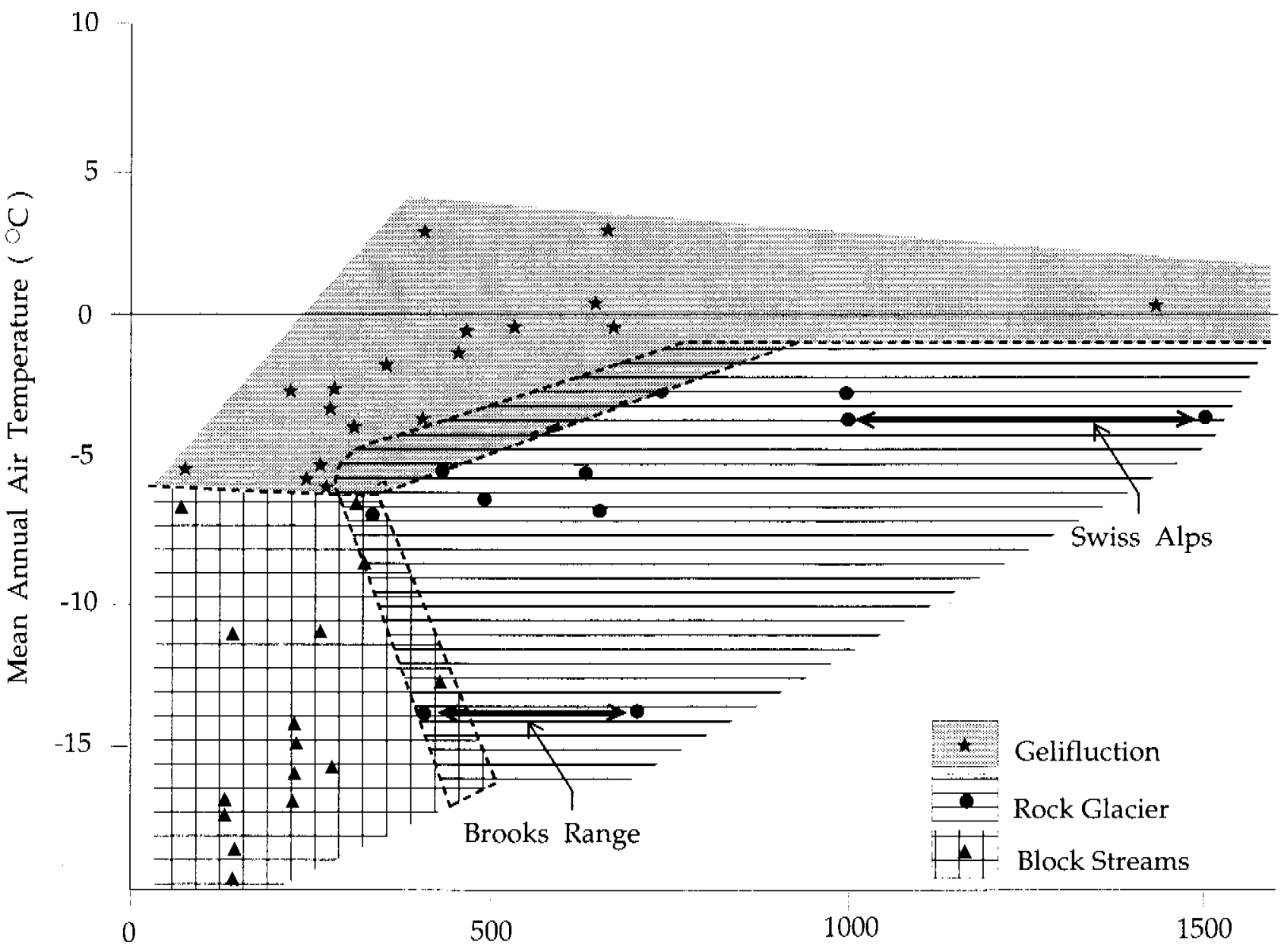

Mean Annual Precipitation ( $\mathrm{mm}$ )

FIG. 13. Distribution of climatic parameters (mean annual air temperature and mean annual precipitation) for mountain landscapes dominated by active block streams, active rock glaciers, and active gelifluction deposits. Examples of typical data are found in Table 1 . 
TABLE 1. Typical climatic data for the three types of mountain permafrost landscapes

\begin{tabular}{|c|c|c|c|c|}
\hline $\begin{array}{l}\text { Dominant landforms } \\
\text { in the landscape }\end{array}$ & Location & $\begin{array}{l}\text { Mean annual air } \\
\text { temperature }\left({ }^{\circ} \mathrm{C}\right)\end{array}$ & $\begin{array}{c}\text { Mean annual } \\
\text { precipitation }(\mathrm{mm})\end{array}$ & References \\
\hline \multirow[t]{14}{*}{ Rock glaciers } & Tungsten, N.W.T.* & -5.7 & 645 & AES, 1982:53 \\
\hline & Columbia Iccfields, Alberta & -2.1 & 930 & AES, n.d., a:47 \\
\hline & Tsischu, N.W.T.* & -8.3 & c. 600 & AES, 1982:51 \\
\hline & Macmillan Pass, Yukon & -7.0 & 650 & Wahl et al, 1987 \\
\hline & $\begin{array}{l}\text { U. Glaciological Station, } \\
\text { Tien Shan, Xinjiang }\end{array}$ & -5.3 & 430 & $\begin{array}{l}\text { Shi Yafeng and Zhang } \\
\text { Xiangson, } 1984: 9\end{array}$ \\
\hline & Dawson City, Yukon & -5.1 & 306 & AES, $1982: 5$ \\
\hline & Spitsbergen & -1.5 to -4.8 & 400 & $\begin{array}{l}\text { Liestøl, 1976:9; Salvigsen and } \\
\text { Elgersma, 1985:148 }\end{array}$ \\
\hline & Brooks Range, Alaska & -14.0 & $400-700$ & Ellis and Calkin, 1980 \\
\hline & Swiss Alps & -4.0 & $1000-2600$ & Haeberli et al., 1992 \\
\hline & French Alps & -2.0 to -4.0 & 800 & Haeberli et al, 1992 \\
\hline & Central Andes $\left(35^{\circ} \mathrm{S}\right)$ & -2.0 & $400-800$ & Corte, 1985 \\
\hline & E. slope, Central Andes $\left(33^{\circ} \mathrm{S}\right)$ & -2.0 to -10.0 & $>950$ & Corte, 1985 \\
\hline & Sunshine ski area, Alberta & -6.9 & $>1000$ & Harris, 1989 \\
\hline & Parkin, Yukon & -6.4 & 473 & Wahl et al., 1987 \\
\hline \multirow[t]{11}{*}{ Gelifluction } & Kunlun Shan, Qinghai & -5.5 & 320 & Cui Zhijiu, 1983 \\
\hline & Kluane Lake, Yukon" & -2.7 & 224 & AES, $1982: 10$ \\
\hline & Haines Junction, Yukon* & -3.2 & 292 & AES, 1982:8 \\
\hline & Burwash Landing, Yukon* & -4.4 & 301 & AES, $1982: 3$ \\
\hline & Niwot Ridge, Colorado & -3.3 & c. 700 & Benedict, 1970 \\
\hline & Aishihik, Yukon* & -4.4 & 256 & AES, 1982:1 \\
\hline & Pink Mountain, B.C.* & -0.5 & 534 & AES, n.d., b:176 \\
\hline & Muncho Lake, B.C.* & -0.7 & 459 & AES, n.d., b:147 \\
\hline & Kapp Linne, Spitsbergen & -4.6 & 400 & Ákerman, 1980 \\
\hline & Central Andes $\left(33^{\circ} \mathrm{S}\right)$ & -0.2 to -4.3 & $400-800$ & Corte, 1985 \\
\hline & Marmot Basin, Jasper, Alberta & -1.8 & 600 & Harris, 1989 \\
\hline \multirow[t]{9}{*}{ Block Streams } & Fenghou Shan, Qinghai & -6.5 & 50 & Guo Dongxin et al., 1993 \\
\hline & Kunlun Shan summit, Qinghai & -6.0 & 320 & Guo Dongxin et al, 1993 \\
\hline & Verkhoyansk, Siberia* & -16.0 & 127 & Critchfield, $1966: 396$ \\
\hline & Aklavik, N.W.T.* & -8.9 & 226 & AES, 1982:18 \\
\hline & Yakutsk, Siberia* & -11.1 & 348 & Koeppe and De Long, 1958:331 \\
\hline & Cape Chelyuskin, Siberia & -13.8 & 96 & Koeppe and De Long, $1958: 330$ \\
\hline & Bulun, Siberia* & -13.8 & 226 & Koeppe and De Long, 1958:330 \\
\hline & Shingle Point, Yukon* & -14.5 & 214 & Wahl et al., 1987 \\
\hline & Komakuk Beach, Yukon* & -11.4 & 136 & AES, $1982: 11$ \\
\hline
\end{tabular}

*Denotes a valley-floor weather station.

\section{Relationships of the Features to Latitude, Altitude, and Aspect}

The three periglacial landscape zones as defined by climate show a marked latitudinal, altitudinal, and aspect zonation. The gelifluction landscapes tend to dominate at the lower latitudes, whereas active rock glaciers and block streams are found in more polar situations. Within a given mountain range, there is often a substantial change in climatic conditions with altitude and aspect. This can often cause a change in the dominant major zonal landform from one part of the mountain chain to another. Good examples of this are found in the Kunlun Shan and Fenghou Shan, along the QinghaiXizang highway, where gelifluction landforms are dominant at altitudes below $5000 \mathrm{~m}$. Above this elevation and beginning on southwest-facing slopes, block slopes appear and quickly replace the gelifluction landforms.

The same situation occurs in North America. In the southcentral portion of the Cordillera of the United States, rock glaciers tend to occur at high altitudes where the moisture regime is sufficiently humid to form interstitial ice, whereas gelifluction forms are dominant elsewhere in this region. In southwestern Alberta, active rock glaciers occur from Jasper northwards, but south of Banff National Park these are replaced by gelifluction forms. On Sheep Mountain, Kluane Lake, Yukon Territory, active block streams appear on southfacing slopes, while gelifluction forms occur on west- and northwest-facing slopes. On the east-facing slope, a rock glacier is found (Johnson, 1973), and others occur at wetter sites with a southwest aspect at lower elevations on the east side of the Slims River (Blumstengel and Harris, 1988). This is because Sheep Mountain has a climate that approximates the intersection of the three boundaries on Figure 13. Thus substantial changes in microenvironment can cause changes in the major zonal permafrost landforms within a given mountain range.

\section{The Edaphic Factor}

One of the major modifiers of the effects of climate on landforms and plants is the nature of the soil. Harris (1989) showed that the different landforms in the Plateau Mountain area compared with those in the Banff-Jasper parks in southwest Alberta appear to be correlated with the edaphic effects of the soil, specifically its drainage and moisture-holding capacity. The climate change from Jasper to Plateau Mountain is small, but the soils are different. At Marmot Basin, Jasper, 
the soils have a higher clay and silt content and hold moisture better, whereas those at Plateau Mountain contain primarily rock, sand, and coarse silt over fissured, porous limestone bedrock. The change from the rock-glacier-dominated landscapes in the mountain parks to the block fields at Plateau Mountain appears to be the result of these edaphic factors, and similar cxamples can be found elsewhere, for example in the Ogilvie Mountains at Engineer Creek at $\mathrm{km} \mathrm{217,}$ Dempster Highway (Harris et al., 1983:79).

\section{CONCLUSIONS}

This zonation is important because it may enable geomorphologists to determine the nature of the local climate on the basis of which landforms are present in alpine permafrost areas. Once such a zonation can be firmly established, it will become possible to look at the distribution of these landforms in the recent geological past and interpret their presence or absence in terms of past climates. Obviously this has tremendous application in identifying and understanding past climatic changes in the alpine areas. Thus, where inactive rock glaciers occur in an area dominated by active gelifluction forms today, e.g., in the higher mountains of Arizona and New Mexico (Barsch and Updike, 1971; Blagbrough and Farkas, 1968), the climate must have been colder but moist at some time in the past. If these landforms can be dated, this will provide the age of the climate under which they formed.

The alpine zone of the mountain areas of the world are dominated by three distinctive landscape types, namely, active rock glaciers, active block streams, and gelifluction landforms. Landscapes dominated by rock glaciers are best known to English-speaking geomorphologists, being found in western Canada, Alaska, the Alps, the central Andes, the Ticn Shan, and the Hindu Kush. Active block streams are widespread in the Urals, Siberia, the northern slopes of the Tibetan Plateau, and northeast Yukon Territory. The active gelifluction landscapes occupy most of the rest of the mountains, especially at low latitudes and in maritime areas.

When the climatic data for typical weather stations at these sites are plotted on a graph of mean annual air temperature (MAAT) and mean annual precipitation, they fall in discrete zones separated by limited areas of overlap. Gelifluction and debris flows are dominant in dry climates where the MAAT exceeds $-5^{\circ} \mathrm{C}$, but give way to rock glaciers in moist climates at a MAAT below about $-1^{\circ} \mathrm{C}$. There is a limited overlap between active block streams and rock-glacier-dominated landscapes between a MAAT of $-5^{\circ} \mathrm{C}$ at $350 \mathrm{~mm}$ precipitation and a MAAT of $-16^{\circ} \mathrm{C}$ at $480 \mathrm{~mm}$, the active block streams occurring under cold, dry climates.

Two recapitulations of the climatic sequence occur: latitudinally and with altitude. In both cases, the climatic changes produce conditions favouring different dominant landforms with latitudinal or altitudinal changes. Thus rock glaciers may occur at the summits of mountains in otherwise arid areas, such as in the Tien Shan. Locally, the edaphic factor of soil moisture-holding capacity and drainage may cause modifications to the pattern, as in southwestern Alberta.

Correct identification of the landforms is essential; for instance, the "Kunlun Shan-type rock glacier" is actually a massive gelifluction deposit, while block streams must be carefully differentiated from stone runs. Care must also be taken to prove whether landforms such as rock glaciers are truly active.

\section{ACKNOWLEDGEMENTS}

The author is indebted to the late Carl Troll, who first suggested to the writer in 1972 that a zonation might exist. Since then, the writer has had the opportunity to visit Iceland, Scandinavia, parts of Siberia, the Alps and Pyrenees, the Southern Alps in New Zealand, parts of the Andes, Tibet, the Tien Shan and Kunlun Shan, and Changbaishan, as wcll as many localities in North America, and he has also benefitted from helpful discussions with numerous colleagues. Finally, J. Alan Heginbottom, A.L. Washburn, and an anonymous reader kindly made many suggestions to improve this paper.

\section{REFERENCES}

AES. 1982. Canadian Climatic Normals. Temperature and Precipitation. The North-Y.T, and N.W.T. Ottawa: Environment Canada, Atmospheric Environment Servicc. $55 \mathrm{p}$.

n.d., a. Canadian Climatic Normals. Temperature and Precipitation. Prairie Provinces. Ottawa: Environment Canada, Atmospheric Environment Scrvice. 429 p.

n.d.,b. Canadian Climatic Normals. Temperature and Precipitation. British Columbia. Ottawa: Environment Canada, Atmospheric Environment Service. 268 p.

AKERMAN, J. 1980. Studies on periglacial geomorphology in West Spitsbergen. Meddelanden Från Lunds Universitets, Geografiska Institution. Avhandlinger $89.297 \mathrm{p}$.

ANDERSSON, J,G. 1906. Solifluction, a component of subaerial denudation. Journal of Geology 14:91-112.

BARSCH, D, 1978. Active rock glaciers as indicators for discontinuous alpine permafrost: An example from the Swiss Alps. Proceedings of the Third International Conference on Permafrost $1: 343-353$.

BARSCH, D., and UPDIKE, R.G. 1971. Periglazialc formung am Kendick Peak in Nord-Arizona wahrend der letzten Kaltzeit. Geographische Helvetica 3:99-114.

BAULIG, H. 1956. Pénéplaines et pódiplaines. Sociêté Belge, études de Gćographie 25:25-58.

BENEDICT, J.B. 1970. Downslope soil movement in a Colorado alpine region: Rates, processes and climatic significance. Arctic and Alpine Research 2:165-226. $6: 55-76$.

BLAGBROUGH, J.W, and FARKAS, S.E. 1968. Rock glaciers in the San Mateo Mountains, south-central New Mexico. American Journal of Science 266:812-823.

BLUMSTENGEL, W., and HARRIS, S.A. 1988. Observations on an active lobatc rock glacier, Slims River valley, St. Elias Range, Canada. In: Permafrost: 5 th International Conference Proceedings. Trondheim: Tapir Press. Vol. 1:689-694.

BRYAN, K. 1946. Cryopedology - The study of frozen ground and intensive frost action with suggestions on nomenclature. American Journal of Science 244:622-642

CAIRNES, L.D. 1912. Differential erosion and equiplanation in portions of Yukon and Alaska. Geological Society of America Bulletin $23: 333-348$.

CAPELLO, C.F. 1947. Le "petraei Semovanti" (= Rock Glaciers) della Alpi Occidentali. La Natura 1:18-23.

CAPPS, S.R. 1910. Rock glaciers in Alaska. Journal of Geology $18: 359 \cdot 375$

CATALANO, L.R. 1926. Contribución al conocimiento de los fenómenos geofísicos atmosféricos. Dirección Gral. de Minas, Geologie c Hidrologie 24. 78 p.

CORTE, A.E. 1976. Rock glaciers. Builetyn Pcryglacjalny 26:175-197. 1985. Comparison of geocryogenic periglacial features and processes in the Andes and Himalayas: The Andes. Actas $3^{\text {iete }}$ Reunion del Grupo Periglacial Argentino. 35-48. 
CRITCHFIELD, H.J. 1966. General climatology. Englewood Cliffs, New Jersey: Prentice Hall Inc. 2nd ed. 420 p.

CUI ZHIJIU. 1983. An investigation of rock glaciers in the Kunlun Shan, China. In: Permafrost: Fourth International Conference Proceedings. Washington, D.C. : National Academy Press. 208-211

CZUDEK, T., and DEMEK, J, 1972. Present-day cryogenic processes in the mountains of eastern Siberia. Geographia Polonica 23:5-20.

EAKIN, H.M. 1916. The Yukon-Koyukuk region, Alaska. U.S. Geological Survey Bulletin 631:67-88.

ELLIS, J.M., and CALKIN, P.E. 1980. Nature and distribution of glaciers, neoglacial moraines, and rock glaciers, East Central Brooks Range, Alaska. Arctic and Alpine Research 11:403-420.

EVIN, M. 1983. Structure et mouvement des glaciers rocheux des Alpes du Sud. These $3^{\circ}$ cycle, Institut de Geographie Alpine, Grenoble. $343 \mathrm{p}$.

FRANCOU, B. 1988. L'eboulisation en haute montagne: Andes et Alpes. Cacn: Centre National de la Recherche Scientifique, Centre de Geomorphologie. $696 \mathrm{p}$.

FRENCH, H.M, and HARRY, D.G. 1992. Pediments and cold-climate conditions, Barn Mountains, unglaciated Northern Yukon, Canada. Geografiska Annaler 74A:145-157.

GARDNER, J. 1979. The movement of material on debris slopes in the Canadian Rocky Mountains. Zeitschrift für Geomorphologie, N.F. 23:45-57.

GEIKE, J. 1894. The Great Ice Age and its relation to the antiquity of man. London: Stanford. 3rd ed. $850 \mathrm{p}$

GIARDINO, J.R. 1983. Movement of ice-cemented rock glaciers by hydrostatic pressure: An example from Mount Mestas, Colorado. Zcitschrift für Geomorphologie, N.F. 27:297-310.

GOBADZHISHVILI, R.G. 1978. Rock glaciers of Georgia. Communique of Georgian Academy of Sciences 90(1):93-96. In Russian.

GORBUNOV, A.P. 1983, Rock glaciers of the mountains of Middle Asia. In: Permafrost: 4th International Conference, Proceedings. Washington, D.C.: National Academy Press. 359-362.

1991. Ploughing blocks of the Tien Shan. Permafrost and Periglacial Processes 2:237-243.

GORBUNOV, A.P., TITKOV, S.N., and POLYAKOV, V.G. 1992. Dynamics of rock glaciers in the northern Tien Shan and the Djungar Ala Tau, Kazakhstan. Permafrost and Periglacial Processes 3:29-39.

GRAF, K. 1984. Climatic conditions for the genesis of solifluction forms in the tropical Andes. Actas, $3^{\text {iere }}$ Reunión del Grupo Periglacial Argentino. 14-16.

GRÖTZBACH, E. 1965. Beobachtungen an Blockströmen im Afghanischen Hindukuschund den in Öztalpen; Mitt. der Geographischen Gesellschaft München 50:175-186.

GUO DONGXIN, ZHAO XIUFENG, WANG BAOLAI, HARRIS, S.A., and DING YUNQING. 1993. A guide to the permafrost and environment of the Qinghai-Xizang Plateau. Observation and Research Station of Qinghai-Xizang Plateau, Academia Sinica. $56 \mathrm{p}$.

HAEBERLI, W. 1985. Creep of mountain permafrost: Internal structure and flow of alpine rock glaciers. Zurich: Mitteilung der Versuchsanstalt für Wasserbau, Hydrologie und Glaziologie 17.221 p. In German,

ed. 1991. Permafrost research sites in the Alps. Field Guide for the Excursions of the International Workshop on Permafrost and Periglacial Environments in Mountain Arcas. Zurich: International Permafrosi Association. 77 p.

HAEBERLI, W., EVIN, M., TENTHOREY, G., KENSEN, H.R., HOELZLE, M., KELLER, F., VONDER MÜHLL, D., WAGNER, S., PELFINI, M., and SMIRAGLIA, C. 1992. Permafrost research sites in the Alps. Excursions of the International Workshop on Permafrost and Periglacial Environments in Mountain Areas. Permafrost and Periglacial Processes 3:189-202.

HARRIS, S.A. 1972. Three modifications to produce more accurate measurements of snowfall and evapotranspiration. Canadian Geographer $16: 271-277$

1973. Three modifications to produce more accurate measurements of snowfall and evapotranspiration: A reply. Canadian Geographer $17: 282-287$

1989. Continentality Index: Its uses and limitations when applied to permafrost in the Canadian Cordillera. Journal of Physical Geography 10:268-282.

HARRIS, S.A., FRENCH, H.M., HEGINBOTTOM, J.A., JOHNSTON, G.H., LADANYI, B., SEGO, DC, and van EVERDINGEN, R.O. 1988. Glossary of permafrost and related ground-ice terms. Ottawa: National Research Council of Canada. Technical Memorandum $142.156 \mathrm{p}$.
HARRIS, S.A., and GUSTAFSON, C.A. 1988. Retrogressive slumps, debris flows and river valley development in icy, unconsolidated sediments on hills and mountains. Zeitschrift für Geomorphologie $32: 441-455$

HARRIS, S.A., and GUSTAFSON, C.A. 1993. Debris flow characteristics in an area of continuous permafrost, St. Elias Range, Yukon Territory. Zeitschrift für Geomorphologie 37:41-56.

HARRIS, S.A., van EVERDINGEN, R.O., and POLLARD, W.H. 1983. The Dempster Highway -- Dawson to Eagle Plain. In: French, H.M., and Heginbottom, J.A., eds. Northern Yukon Territory and Mackenzic Delta, Canada. Guidebook 3. 4th International Conference on Permafrost, Fairbanks, Alaska. 65-86.

HASTENRATH, S., and WILKINSON, J. 1973. A contribution to the periglacial morphology of Lesotho, southern Africa. Biuletyn Peryglacjalny $22: 157-167$.

HUGHES, O.L. 1972. Surficial geology and land classification. Proceedings, Canadian Northern Pipeline Conference, Ottawa, Ontatio, February 1972, Ottawa: National Research Council of Canada, Associate Committee on Geotechnical Research. Technical Memorandum 104:17-24.

IGARZABAL, A. 1983. Aspecto geocriogénico de Puna y Cordillera

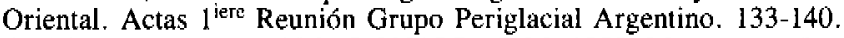

JACKSON, L.E. Ir. and MacDONALD, G.M. 1980. Movement of an ice-cored rock glacier, Tungsten, N.W.T., Canada, 1963-1980. Arctic 33:842-847.

JOHNSON, J.P. 1973. Some problems in the study of rock glaciers. In: Fahey, B.D., and Thompson, R.D., eds. Research in polar and alpine geomorphology. Guelph Symposium on Geomorphology, 1973. 3rd Proceedings. Norwich: GeoAbstracts Ltd. 84-94.

JORRE, G. 1933. Problème des 'terrasses goleta' sibériennes. Revue de Géographie Alpinc 21:347-371.

JOYCE, J.R.F. 1950. Stone runs of the Falkland Islands. Geological Magazine 87:105-116.

KERSHAW, G.P. 1978. Rock glaciers in the Cirque Lake area of the Yukon-Northwest Territories. The Albertan Geographer 14:61-88.

KING, C.A.M., and HIRST, R.A. 1964. The boulder-fields of the Alland Islands. Fennia 89(2), 41 p.

KOEPPE, C.E., and De LONG, G.C. 1958. Weather and climate. New York: McGraw-Hill Book Co. Inc. 341 p.

KOTARBA, A. 1984. Elevational differentiation of slope geomorphic processes of the Polish Tatra Mountains. Studia Geomorpholocia Carpatho-Balcanica 18:117-133.

KOTARBA, A., and STRÖMQUIST, L. 1984. Transport, sorting and deposition processes of alpine debris slope deposits in the Polish Tatra Mountains. Geografiska Annaler 66A:285-294.

LIEST OL, O. 1976. Pingos, springs and permafrost in Spitsbergen. Norsk Polarinstitutt Ärbok, 1975: 7-29.

LOUGHRAN, R.J., and LOUGHRAN, A.I. 1979. Stone chute development on a limestone scree. Earth Surface Processes and Landforms $4: 191-197$

LUCKMAN, B.H. 1988. Debris accumulation patterns on talus slopes in Surprise Valley, Alberta. Géographie Physique et Quaternaire 42:247-278.

LUCKMAN, B.H., and CROCKETT, K.J. 1978. Distribution and characteristics of rock glaciers in the southern part of Jasper National Park, Alberta. Canadian Journal of Earth Sciences 15:540-550.

MACKAY, J.R. 1966. Segregated epigenetic ice and slumps in permafrost, Mackenzie Delta Area, N.W.T. Geographical Bulletin 8:59-80.

MARANGUNIC, C. 1976. El glaciar de roca Pedregoso, Rió Colorado V Región. $1^{\text {ierc }}$ Congresso Geologica Chilano. 71-80.

MAYEWSKI, P.A., JESCHKE, P.A., and AHMAD, N. 1981. An active rock glacier, Wavbal Pass, Jammu and Kashmir Himalaya, India. Journal of Glaciology 27(95):201-202.

McROBERTS, E.C., and MORGENSTERN, N.R. 1974. The stability of thawing slopes. Canadian Geotechnical Journal 11:447-469.

PALGOV, N.N. 1948. Glaciation of Bolshaya Almatinka source area (Zailiysky Ala Tau). Izvestya an Kazakhstan SSR. Geography, Alma Ata 58(2):39-71. In Russian.

PÉREZ, F.L. 1985. Surfiçial talus movement in an Andean paramo of Venezuela. Geografiska Annaler 67A:221-237.

1988. The movement of debris on a high Andean talus. Zeitschrift für Geomorphologie, N.F. 32:77-99.

1989. Talus fabric and particle morphology on Lassen Peak, California, Geografiska Annaler 71A:43-57.

1993. Talus movement in the High Equatorial Andes: A synthesis of ten years of data. Permafrost and Periglacial Processes 4:199-215. 
RAMPTON, V.N., and MACKAY, J.R. 1971. Massive ice and icy sediments throughout the Tuktoyaktuk Peninsula, Richards Island, and nearby areas, District of Mackenzie. Geological Survey of Canada, Paper 71-21. $16 \mathrm{p}$

RATHJENS, C. 1978. Klimatische bedingungen der Solifluktionsstufe in sommertrockenen Hochgebirge, am Beispiel des Afghanischen Hindukusch. 7eitschrift für Geomorphologic, N.F., Suppl. 30:132-142.

ROMANOVSKII, N.N., and TYURIN, A.I. 1974. Facies characteristics of rock streams of Southern Yakutia and Northern Transbaikalia. Geologia 4. Vestnik Moskovskogo Universitets. In Russian.

1983. Rock stream deserption. Proceedings, 4th International Permafrost Conference. Washington, D.C.: National Academy Press, $1078-1082$.

1986. Kurums. Biuletyn Peryglacjalny $31: 249-259$

SALVIGSEN, O, and ELGERSMA, A. 1985. Large-scale karst features and open taliks at Vardeborgsletta, outer Isfjorden, Svalbard. Polar Research, 3 n.s.:145-153.

SCHUBERT, C. 1969. La zona del Páramo: Morfología glacial y Periglacial de los Andes de Venezuela. Actas del Seminario de Mérida, Venczucla, El Medio Ambiente Páramo. 1-28.

SCHWEI\%ER, G. 1972. Klimatisch bedingte geomorphologische und glaziologische züge der hochregion vorderasiatischer gebirge (Iran und Ostanatolien). In: Troll, C., ed. Geoccology of the high-mountain regions of Eurasia. Wiesbaden: Franz Steiner Verlag GMBH, 221-236.

SHI YAFENG and ZHANG XIANGSONG. 1984. Guide to the Tienshan Glaciological Station of China. Lanzhou: Lanzhou Institute of Glaciology and Geocryology, Academia Sinica. 31 p.
SMITH, D.T. 1987. Late Holocene solifluction lobe activity in the Mount Rac area, southern Canadian Rocky Mountains. Canadian Journal of Earth Sciences 24:1634-1642.

1988. Rates and controls of soil movement on a solifluction slope in the Mount Rae area, Canadian Rocky Mountains. Zeitschrift für Geomorphologic 70: Supplement Band, 25-44.

SPARROW, G.W.A. 1967. Pleistocene periglacial topography in Southern Africa. Journal of Glaciology 6:551-559.

TITKOV, S.N. 1985. Rock glaciers of the Ak Shiyrack mountain mass. In: Regional and Engineering Geocryological Investigations. Yakutsk: Permafrost Institute. 80-88. In Russian.

TROLL, C. 1947. Die Fomen der Solfluktion und die periglaziale Boden abtragung. Erdkunde 1:162-175. , ed. 1972. Geoecology of the high-mountain regions of Eurasia. Wiesbaden: Franz Steiner Verlag GMBH. 299 p.

WAHL, H.E., FRASER, D.B., HARVEY, R.C., and MAXWELL, J.B. 1987. Climate of the Yukon. Ottawa: Environment Canada. Atmospheric Environment Service, Climatological Series 40. 323 p.

WAHRHAFTIG, C., and COX, A. 1959. Rock glaciers in the Alaska Range. Bulletin of the Geological Society of Amcrica 70:383-436.

WASHBURN, A.L. 1973. Periglacial processes and environments. London: Edward Arnold, Ltd. 320 p. 1979. Geocryology. London: Edward Arnold, Ltd. 406 p.

ZHIGAREV, L.A. 1967. Prichiny i Mehanizm Razvitiya Soliflyuktsli. Moscow, Akademie Nauk, Izdatel'stvo. 158 p. In Russian. 